\title{
CLINICAL AND DEMOGRAPHIC PROFILE OF CHILDREN HOSPITALIZED WITH MEASLES INFECTION IN PESHAWAR, PAKISTAN
}

\section{Faheemullah Khan $^{\otimes 1}$, Amin Jan Gandapur', Iftikhar Ali ${ }^{2,3}$, Rifaq Zeb ${ }^{4}$, Wiqar Ahmad ${ }^{5}$}

\begin{abstract}
OBJECTIVE: To record the clinical and demographic characteristics of measles in patients hospitalized with measles infection in Peshawar, Pakistan.

METHODS: A retrospective review of medical records from December 2016 to January 2017 was conducted at Northwest General Hospital and Research Centre, Peshawar. A total of 182 measles patients' data was retrieved and recorded in predesigned format which included information on demographics, clinical features, complications and outcome. Both descriptive and inferential statistics were used for data analysis.
\end{abstract}

RESULTS: Out of 182 patients, 1 18(64.8\%) were males. The mean age was $24.1 \pm 2.5$ months. The average length of hospital stay was $3.09 \pm 2.58$ days. The most common complication was pneumonia 99 (54.4\%), followed by diarrhea $54(29.7 \%)$ and encephalitis I I (6.0\%). The patients were categorized in to two age groups, pre-vaccination group ( $\leq 9$ months age) and post-vaccination group (>9 months age). Significant number of cases 54 (30\%) were seen in age group $\leq 9$ months. Only $45(35 \%)$ cases in age group $>9$ months received the scheduled measles vaccination. Multivariate regression analysis revealed that presence of Koplik spots [AOR $=0.25 \mathrm{I}, \mathrm{Cl} ; 0.074-0.853, \mathrm{p}=0.027]$, high lymphocyte count $[\mathrm{AOR}=0.205, \mathrm{Cl} ; 0.092-0.453, \mathrm{p}<0.00 \mathrm{I}]$ and being unvaccinated in general $[A O R=2.546, \mathrm{Cl} ; \mathrm{I} .185-5.469, \mathrm{p}=0.017]$ were found to be significantly associated with age group $>9$ months. Majority of patients were from the Peshawar $(n=95)$ followed by Kohat $(n=10)$,

CONCLUSION: Pneumonia was the commonest complication followed by diarrhea. Vaccination history was very poor and significant number of patients were seen in age group $<9$ months of age.

KEY WORDS: Measles (MeSH); Vaccination (MeSH); Pneumonia (MeSH), Diarrhea (MeSH).

THIS ARTICLE MAY BE CITED AS: Khan F, Gandapur AJ, Ali I, Zeb R, Ahmad W. Clinical and demographic profile of children hospitalized with measles infection in Peshawar, Pakistan. Khyber Med Univ J 2019; I (2):7984. DOI: $10.35845 / \mathrm{kmuj} .2019 .18662$

\section{INTRODUCTION}

M easles is a highly contagious viral illness, usually transmitted through respiratory droplets and affecting predominantly the early age group ( $<5$ years). The incubation period is estimated to last 10 to 14 days. The prodromal phase is characterized by onset of fever accompanied by cough, coryza, and/or conjunctivitis. The fever is followed by the characteristic maculopapular rash, generally 3 to 5 days later. The individuals are infectious mostly during the period ( 7 days before and 7 days after the rash appears). ${ }^{1,2}$ Measles affects the immune system, especially in the very young age group, leading to complications like pneumonia, diarrhea and encephalitis, that can lead to death. ${ }^{3}$

Despite the availability of a safe and cost-effective vaccine, measles is still a
I. Department of Pediatric Medicine Northwest General Hospital and Research Centre, Peshawar, Pakistan Email $\bowtie$ : islamianfellow@hotmail.com Contact \#: $\quad$ +92-3428153763

2. Department of Pharmacy, University of Swabi, Khyber Pakhtunkhwa, Pakistan.

3. Paraplegic Center, Hayatabad, Peshawar, Pakistan.

4. Department of Pediatric Medicine, Khyber Teaching Hospital, Peshawar, Pakistan.

5. Department of Internal Medicine, Northwest General Hospital and Research Centre, Peshawar, Pakistan

$\begin{array}{ll}\text { Date Submitted: } & \text { September 20, } 2018 \\ \text { Date Revised: } & \text { May 24, 2019 } \\ \text { Date Accepted: } & \text { May 25, 2019 }\end{array}$

leading cause of mortality among young children, with greatest in the regions having poor access to primary health care. $^{4-6}$ In 20I I, it contributed 158000 deaths throughout the world, while in 2014 total recorded deaths were 0.1 Imillion or 314 deaths every day. ${ }^{7}$ According to the World Health Organization(WHO) figures, measles related deaths have been decreased by $79.0 \%$ from 2000 to $2014 .^{8}$ Measles elimination was made a component of Millennium Development Goal 4 (MDG-4). Being a member of Eastern Mediterranean Region (EMR) Pakistan made a commitment in 1997 to eliminate measles by $2010 .^{\circ}$ The goal set by EMR office was to reduce measles incidence to One per million and mortality by $90 \%$ by $2010 .^{10}$

Despite being part of the WHO's new Global Measles and Rubella Strategic Plan 20l2-2020, Pakistan still experiences a high number of outbreaks and deaths due to measles." In 2012, 14 000 cases were reported, resulting in 306 deaths. ${ }^{12}$ WHO reported 94 measles outbreaks in the first three weeks of January 2013, with Punjab recording 25 and Baluchistan 33 outbreaks. Simultaneously, I 2 I I measles cases were reported in Sindh, 290 in Khyber Pakhtunkhwa and 483 in Baluchistan. It claimed lives of 103 children throughout the country from January I to January 19.'

According to the Expanded Program for Immunization (EPI) schedule for Pakistan; Measles immunization is 
TABLE I: CLINICAL CHARACTERISTICS OF THE PATIENTS $(n=182)$

\begin{tabular}{|c|c|c|}
\hline \multicolumn{2}{|l|}{ Characteristics } & \multirow{2}{*}{$\begin{array}{l}\mathbf{N}(\%) \\
49(26.9 \%) \\
133(73.1 \%)\end{array}$} \\
\hline Fever & $\begin{array}{l}\text { Low grade } \\
\text { High grade }\end{array}$ & \\
\hline Cough & $\begin{array}{l}\text { Present } \\
\text { Absent }\end{array}$ & $\begin{array}{l}139(76.4 \%) \\
43(23.6 \%)\end{array}$ \\
\hline Rash & $\begin{array}{l}\text { Present } \\
\text { Absent }\end{array}$ & $\begin{array}{l}166(91.2 \%) \\
16(8.8 \%)\end{array}$ \\
\hline Eyes & $\begin{array}{l}\text { Normal } \\
\text { Inflamed }\end{array}$ & $\begin{array}{l}167(91.8 \%) \\
15(8.2 \%)\end{array}$ \\
\hline Kopliks spot & $\begin{array}{l}\text { Present } \\
\text { Absent }\end{array}$ & $\begin{array}{c}17(9.3 \%) \\
165(90.7 \%)\end{array}$ \\
\hline Hemoglobin (g/dl) & $\begin{array}{l}\leq 10 \mathrm{~g} / \mathrm{dl}(\text { Anemia }) \\
>10 \mathrm{~g} / \mathrm{dl}\end{array}$ & $\begin{array}{c}47(25.8 \%) \\
135(74.2)\end{array}$ \\
\hline Leucocyte count & $\begin{array}{l}\text { Normal }\left(\leq|| \times \mid 0^{3}\right) \\
\text { Increased }\left(>|| x \mid 0^{3}\right)\end{array}$ & $\begin{array}{l}123(67.6 \%) \\
59(32.4 \%)\end{array}$ \\
\hline Neutrophil count & $\begin{array}{l}\text { Normal } \\
\text { Increased }\end{array}$ & $\begin{array}{l}150(82.4 \%) \\
32(17.6 \%)\end{array}$ \\
\hline Lymphocyte count & $\begin{array}{l}\text { Normal } \\
\text { Increased }\end{array}$ & $\begin{array}{l}105(57.7 \%) \\
77(42.3 \%)\end{array}$ \\
\hline X-Ray Chest & $\begin{array}{l}\text { Normal } \\
\text { Suggestive of pneumonia }\end{array}$ & $\begin{array}{l}86(47.3 \%) \\
96(52.7 \%)\end{array}$ \\
\hline Vaccination status & $\begin{array}{l}\text { Unvaccinated } \\
\text { Vaccinated }\end{array}$ & $\begin{array}{l}83(45.6 \%) \\
99(54.4 \%)\end{array}$ \\
\hline $\begin{array}{l}\text { Measles } \\
\text { vaccination }\end{array}$ & $\begin{array}{l}\text { Unvaccinated } \\
\text { Vaccinated }\end{array}$ & $\begin{array}{l}137(75.3 \%) \\
45(24.7 \%)\end{array}$ \\
\hline Pneumonia & $\begin{array}{l}\text { Present } \\
\text { Absent }\end{array}$ & $\begin{array}{l}99(54.4 \%) \\
83(45.6 \%)\end{array}$ \\
\hline Diarrhea & $\begin{array}{l}\text { Present } \\
\text { Absent }\end{array}$ & $\begin{array}{l}54(29.7 \%) \\
128(70.3 \%)\end{array}$ \\
\hline Convulsions & $\begin{array}{l}\text { Present } \\
\text { Absent }\end{array}$ & $\begin{array}{c}14(7.7 \%) \\
168(92.3 \%)\end{array}$ \\
\hline Encephalitis & $\begin{array}{l}\text { Present } \\
\text { Absent }\end{array}$ & $\begin{array}{c}1 \mathrm{I}(6.0 \%) \\
17 \mathrm{I}(94.0 \%)\end{array}$ \\
\hline & $\begin{array}{l}\text { Pharyngitis } \\
\text { Pneumothorax }\end{array}$ & $\begin{array}{l}11(6.0 \%) \\
3(1.6 \%)\end{array}$ \\
\hline $\begin{array}{l}\text { Other } \\
\text { complications }\end{array}$ & $\begin{array}{l}\text { Sinusitis } \\
\text { Sepsis }\end{array}$ & $\begin{array}{l}\mathrm{I}(0.5 \%) \\
\mathrm{I}(0.5 \%)\end{array}$ \\
\hline & $\begin{array}{l}\text { Sub-acute Sclerosing } \\
\text { Panencephalitis }\end{array}$ & $\mathrm{I}(0.5 \%)$ \\
\hline $\begin{array}{l}\text { Length of hospital } \\
\text { stay }\end{array}$ & $\begin{array}{l}\leq 7 \text { days } \\
>7 \text { days }\end{array}$ & $\begin{array}{c}172(94.5 \% \\
10(5.5 \%)\end{array}$ \\
\hline Outcome & $\begin{array}{l}\text { Discharged } \\
\text { Died }\end{array}$ & $\begin{array}{l}|8|(99.5 \%) \\
\mid(0.5 \%)\end{array}$ \\
\hline
\end{tabular}

recommended at 9 months of age with the booster dose at 12 to 15 months of age. WHO recommended that, there should be more than $90 \%$ coverage of both doses of measles vaccine. ${ }^{3}$

Vaccination is the only hope towards measles elimination. But unfortunately Pakistan records very low vaccination coverage, being $75 \%$ (initial dose) and $53 \%$ (booster dose) in $201 \mathrm{I}$ while in the same year nearly 0.9 million children did not receive their first dose of measles vaccination, resulting in multiple outbreaks in country. For the year 2014 , Pakistan showed overall vaccination coverage of $63 \%$, with suspected measles cases approximately
2555 and laboratory confirmed cases $1362 .^{15}$ According to the study done in Karachi between 2014-16, the measles vaccination coverage was very low, being $34.9 \%$ at 9 -month age declining to $22.7 \%$ at 15 -month age. ${ }^{16}$ Keeping in view the burden of measles cases, we conducted this study to record the clinical and demographic characteristics of measles in patients hospitalized with measles infection in Peshawar, Pakistan.

\section{METHODS}

A retrospective review of medical records from January 2016 to December 2017 was conducted at Northwest General Hospital and Research Centre, Peshawar, Pakistan. This is a private sector hospital covering vast areas in and around Peshawar and neighboring Afghanistan. Mode of payment ranges from fee-for-service, corporate coverage and the newly launched government scheme of Sehat Insaf Card.

The data was extracted from both patient file and electronic medical record, containing measles cases using a structured format. Patients aged $0-12$ years were included in the study. Those with congenital disorders, immunodeficiency disorders and having malignant disorders were excluded. Information on demographics like, age, gender, locality etc., clinical features, immunization status, laboratory investigations, complications and clinical outcome was noted or recorded. Measles cases were divided in two age groups, pre-vaccination group ( $\leq 9$ months) and post-vaccination group (>9 months). The data was analyzed by SPSS version 20 for Windows. Frequency and percentages were calculated for categorical data and mean (standard deviation [SD]) for numerical data. For comparison chi-square or Fisher's exact test where appropriate was used. $P$ value $<0.05$ was considered significant for all statistical tests. A logistic regression analysis was used to calculate the adjusted odds ratios (AOR) and their $95 \%$ confidence intervals. Variables having P-value of $<0.25$ at univariate analysis were entered into multivariate analysis.

The study was approved by the ethics 


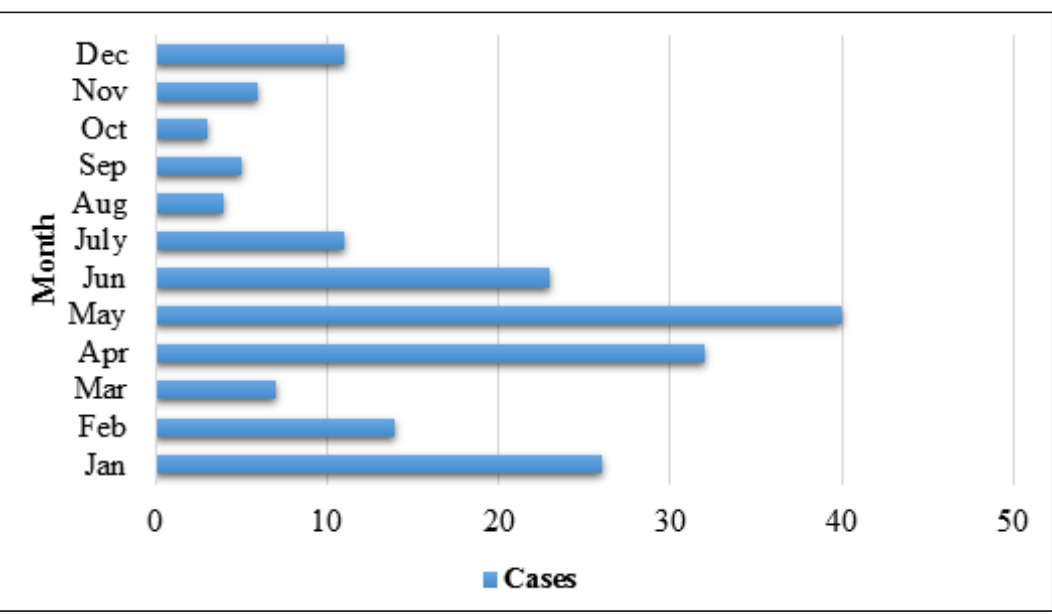

Figure I: Month wise distribution of measles cases

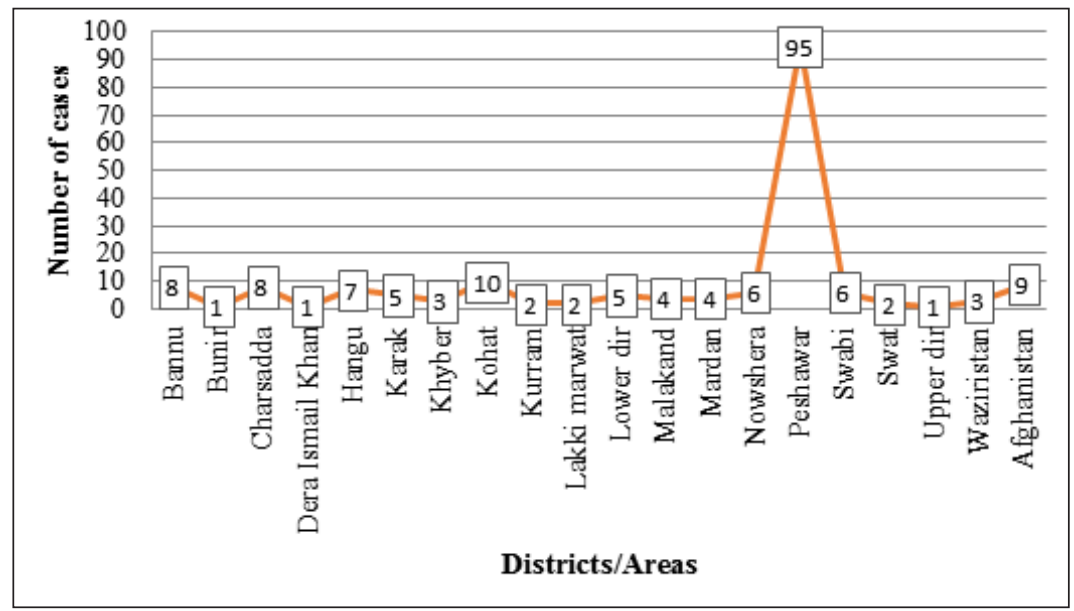

Figure 2: Area wise distribution of measles cases [including patients from Afghanistan $(n=9)]$

review committee of the Northwest General hospital and Research Centre [Ref No: NwGH/Res/approv/5].

\section{RESULTS}

Out of 182 patients included in the study, I I8(64.8\%) were males and $64(35.2 \%)$ were females. The mean (SD) age was $24.1 \pm 2.5$ months and median age was 12 months.

Rash was observed in 166(91.2\%) patients while koplik spots were present in $9.3 \%$ of the patients. The radiological investigations (Chest X-ray) were suggestive of pneumonia in 96(52. $7 \%)$. Of the total patients $45.6 \%$ did not receive the age specific routine vaccination and $75.3 \%$ did not receive the measles vaccination. Overall,
Afghanistan (Figure 2).

The patients were categorized into two age groups, pre-vaccination age group $(\leq 9$ months $=54)$ and the postvaccination age group ( $>9$ months $=128$ ). Significant difference in lymphocyte count was observed between two age groups $(p<0.00 \mathrm{I})$ and similarly Koplik spots was also found to be significant between the two groups $(p=0.027)$, however no significant difference was found regarding the length of hospital stay and complications (Pneumonia, diarrhea, encephalitis) between the two groups (Table II). Both the groups had same clinical presentation (fever, cough and rash). More than half of the cases in prevaccination age group $\leq 9$ months developed Pneumonia (almost 63\%) as compared to post-vaccination age group $>9$ months (50\%) however the difference was in-significant. Variables found to be significant (cut off value $<0.25)$ at univariate analysis were entered into multivariate logistic regression analysis. Among the variables, three variables, presence of Koplik spots $[\mathrm{AOR}=0.25 \mathrm{I}, \mathrm{Cl} ; 0.074$ $0.853, p=0.027$, high lymphocyte level $[A O R=0.205, \mathrm{Cl} ; 0.092-0.453$, $\mathrm{p}<0.00 \mathrm{I}]$ and being unvaccinated $[A O R=2.546, \mathrm{Cl} ; \mathrm{I} .185-5.469$, $\mathrm{p}=0.017$ ] were found to be significantly associated with age group $>9$ months (Table III).

\section{DISCUSSION}

Our study confirms male preponderance, this finding is consistent with a study conducted in Bangladesh. ${ }^{17}$ Moreover same results have also been reported locally by Khan, et al..$^{18}$ and Saleem, et al. ${ }^{19}$

The mean age of measles cases in present study was $24.13 \pm 2.5$ months. A study conducted by Tariq, et al. ${ }^{20}$ on measles patients in Rawalpindi reported mean age of 32 months. Another research conducted by Furrukh, et al. ${ }^{21}$ also reported mean age of 32 months. all the seasons of the year though the majority of cases were seen during the winter and a hot, dry spring season (March through May) (Figure I). Majority of patients were from the district Peshawar followed by Kohat, moreover 9 patients were from
One unanticipated result in our study is that $54(30 \%)$ cases, who presented with measles, were $\leq 9$ months of age while $70 \%$ children were $>9$ months of age. While other studies showed that 
TABLE II: ASSOCIATIONS OF TWO AGE GROUPS WITH DEMOGRAPHICS AND CLINICAL CHARACTERISTICS $(n=182)$

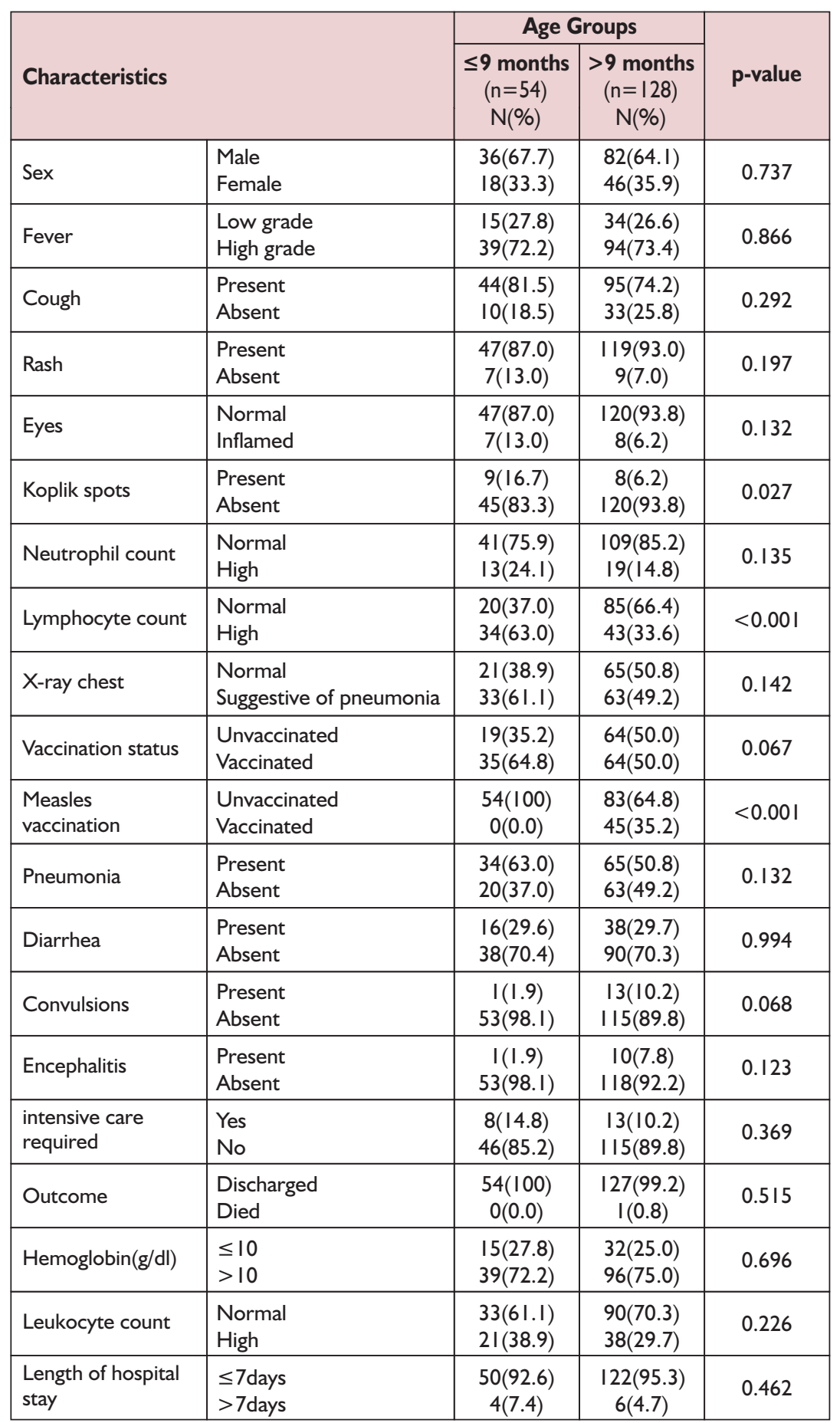

I I.5\% to $23.4 \%$ of children were less than 9 months of age. ${ }^{19,20}$ In a similar study by Akramuzzaman et al in Bangladesh found $23 \%$ of measles cases before 9 months of age and 19\% between 9-II months of hospitalized increased incidence of measles cases in $\leq 9$ months of age. Studies by Zahidie et al and Silfverdal et al described that $>3$ months of breast feeding can modify the outcome of measles in comparison to those who are not breastfed. ${ }^{23,24}$ Such high percentage of measles patients younger than 9 months implies need for further studies and proper investigations to find out incidence and prevalence of measles in infants from birth onwards.

In this study Pneumonia was the most common complication observed among the measles cases, followed by diarrhea and encephalitis, and very severe pneumonia with respiratory failure was the reason behind the single death in age group $>9$ months. Similar complications are observed by various studies.

Measles is endemic in this part of the world with periodic epidemics occurring every two to three years. Figure one depict the monthly hospital admissions. The disease is more common during the winter and spring seasons as supported by our study results. More than half of measles cases 95(52\%) were reported from Peshawar District of Khyber Pakhtunkhwa. Since our study center was Peshawar, hence most cases were from Peshawar and its surrounding areas.

The Expanded Program on Immunization (EPI) was initiated in Pakistan in 1978 under the umbrella of World Health Organization with the aim of reducing the mortality due to vaccine preventable illnesses. ${ }^{26}$ Measles immunization is a part of EPI, consisting of two doses, initial dose administered at 9 months of age and the booster dose at 12 to 15 months of age. ${ }^{14}$ Despite all the global support measles is still a major public health problem in Pakistan. In 20 II Pakistan recorded very low vaccination coverage, being $75 \%$ (initial dose) and 53\%(booster dose)." Measles vaccination coverage serves as an indicator of the quality of immunization programs. ${ }^{27}$

According to our study, only $35 \%$ of the cases in age group $>9$ months were vaccinated, either with a single or two doses however no documentary proof 
TABLE III: MULTIVARIATE LOGISTIC REGRESSION ANALYSIS OF THE PATIENT'S CHARACTERISTICS ASSOCIATED WITH AGE GROUP > 9 MONTHS

\begin{tabular}{|c|c|c|c|c|c|}
\hline \multirow[b]{2}{*}{ Characteristics } & \multicolumn{2}{|c|}{ Age groups } & \multirow[b]{2}{*}{$\begin{array}{c}\text { Adjusted } \\
\text { Odd Ratios } \\
\text { (AOR) }\end{array}$} & \multirow[b]{2}{*}{$95 \% \mathrm{Cl}$} & \multirow[b]{2}{*}{ p-value } \\
\hline & $\begin{array}{c}\leq 9 \text { months } \\
(n=54) \\
N(\%)\end{array}$ & $\begin{array}{c}>9 \text { months } \\
(n=128) \\
N(\%)\end{array}$ & & & \\
\hline $\begin{array}{l}\text { Koplik spots } \\
\text { Present } \\
\text { Absent }\end{array}$ & $\begin{array}{c}9(16.7) \\
45(83.3)\end{array}$ & $\begin{array}{c}8(6.2) \\
120(93.8)\end{array}$ & $\begin{array}{c}0.25 \mathrm{I} \\
\text { Reference }\end{array}$ & $0.074-0.853$ & 0.027 \\
\hline $\begin{array}{l}\text { Lymphocyte count } \\
\text { Normal } \\
\text { High }\end{array}$ & $\begin{array}{l}20(37.0) \\
34(63.0)\end{array}$ & $\begin{array}{l}85(66.4) \\
43(33.6)\end{array}$ & $\begin{array}{c}\text { Reference } \\
0.205\end{array}$ & $0.092-0.453$ & $<0.001$ \\
\hline $\begin{array}{l}\text { Vaccination status } \\
\text { Unvaccinated } \\
\text { Vaccinated }\end{array}$ & $\begin{array}{l}19(35.2) \\
35(64.8)\end{array}$ & $\begin{array}{l}64(50.0) \\
64(50.0)\end{array}$ & $\begin{array}{c}2.546 \\
\text { Reference }\end{array}$ & $1.185-5.469$ & 0.017 \\
\hline
\end{tabular}

of the vaccination status was available. Furrukh et al reported $61.1 \%$ of patients were not vaccinated against measles while in a study conducted at Khyber Teaching Hospital, Peshawar $25 \%$ of patients were not vaccinated. ${ }^{21,28}$ The coverage for measles vaccination was even lower in a Nigerian study that showed higher proportion of unvaccinated children i.e. $77.9 \%{ }^{29}$ This low coverage of measles vaccination in our study $(35 \%)$ is quite high and alarming, in spite of our health care systems strenuous efforts and contributions in the field of EPI. Occurrence of measles in vaccinated children (35\%) also raises questions about efficacy and effectiveness of vaccine. Whether the problem is with the vaccine, its method of administration, usage after being expired or the failure of maintenance of a proper cold chain; issues that need to be explored on urgent basis. Low immunization coverage is a composite in this part of the world, various studies have reported different contributing factors to this dilemma. ${ }^{19,30}$ Among them socioeconomic, cultural and poor health infrastructures are the major factors.

Some other factors associated with increased measles incidence in literature are budgetary constraints, mismanagement, poor primary health services, security situation, negligence/lack of awareness among parents, shortage in number of vaccinators, poor cold chain maintenance, floods and malnutrition. ${ }^{19,30}$

\section{CONCLUSION}

Significant numbers of cases were seen in $\leq 9$ months of age. The most common complication was pneumonia, followed by diarrhea and encephalopathy in frequency. Measles vaccination coverage is very poor in current study population. Vaccination at early age should be initiated in epidemic or higher endemic situations.

\section{LIMITATIONS}

The worth mentioning limitations related to this study are its design and setting (single center and hospital based) and hence may not be representative of the whole community. Being a retrospective study, information on detail socio-demographic and contact history was not available and no documentary proof of measles vaccination was obtained, only the verbal response of parents as "yes" or 'no" was relied upon.

\section{REFERENCES}

I. Caldararo S. Measles. Pediatr Rev 2007;28(9):352-4. DOI:10.1542/ pir.28-9-352.

2. Fields BN, Knipe DM, Howley PM. Fields virology. Philadelphia: Wolters Kluwer Health/Lippincott Williams \& Wilkins; 2007.

3. World Health Organization. Measles 2018. [Cited on: 2019, March 18]. Available from URL: https://www. detail/measles.

4. World Health Organization. Measles 2009. [Cited on: September 17, 2018]. Available from URL: http://www.who.int/mediacentre/ factsheets/fs286/en/.

5. World Health Organization. Measles who.int/news-room/fact-sheets/
2013 (updated 2013 Feb 20) [Cited on: September 17, 2018]. Available from URL: http://www.who.int/ mediacentre/factsheets/fs286/en/ index.html.

6. Grais R, Dubray C, Gerstl S, Guthmann J, Djibo A, Nargaye K, et al. Unacceptably high mortality related to measles epidemics in Niger, Nigeria, and Chad. PLoS Med 007;4(I):el6. DOI:I0.1371/journal. pmed.00400I6.

7. World Health Organization. Measles 2015. [Cited on: September 17, 2018]. Available from URL: http://www.who. int/mediacentre/ factsheets/fs286/e(I)n/;20I5.

8. World Health Organization. Measles vaccination has saved an estimated I7.I million lives since 2000, 2015. [Cited on: September 17, 2018]. Available from URL: http://www.who. int/mediacentre/news/releases/2015/ measles-vaccination/en/; 2015.

9. Gaafar T, Moshni E, Lievano F. The challenge of achieving measles elimination in the Eastern Mediterranean Region by 2010 . J Infect Dis 2003; 187 (Supplement_I): SI64-S7I.DOI:I0. 1086/368035.

10. World Health Organization. Progress towards reducing measles mortality and eliminating measles, WHO Eastern Mediterranean Region, 19972007. Wkly Epidemiol Rec 2008;83(II):97-104

II. Khan T, Qazi J. Measles outbreaks in Pakistan: causes of the tragedy and future implications. Epidemiol Rep 20I4;2(I):I-5. DOI: 10.7243/205499।I-2-I.

12. Riaz H. Public health failings behind Pakistan's measles surge. The Lancet 2013;38I(9862):189. DOI: 10.1016/ s0l40-6736(I3)60072-0.

13. Chaudhry A. WHO reports 94 measles outbreaks across Pakistan in January. Daily DAWN. 2013. [Cited on: September 17, 2018]. Available from URL: https://www. dawn.com/news/78II 20.

14. Masud T, Navaratne KV. The expanded program on immunization in Pakistan: recommendations for improving performance 2012. [Cited on: September 17, 2018]. Available from URL: http://siteresources. worldbank.org/HEALTHNUTRITIO 
NANDPOPULATION/Resources/28 |627-1095698|40 |67/ EPlinPakistan. pdf.

15. World Health Organization. Reported measles cases and incidence rates by WHO Member States 2013, 2014 as of II February 2015. 2015 [Cited on: September 17, 2018]. Available from URL: http://www.who.int/ immunization/monitoring surveillance /burden/vpd/surveillance_type/active/ measlesreportedcasesbycountry.pdf.

16. Siddiqui S, Akbar M, Mehtab A, Zafar $M$, Shahid S, Ahmed S, et al. Frequency of immunisation of children upto five years of age according to vaccination card in Karachi-A multicentre study. Ann Abbasi Shaheed Hosp Karachi Med Dent Coll 20 I7;22(I): 12-9.

17. Ahsan MR, Al Mamun A, Alam HSK, Sarker PK, Makbul S, Kabir R, et al. Occurrence of Measles among Children Admitted in Tertiary Care Hospital. Bangladesh J Child Health 2018;42(I):15-8.

18. Khan M, Khan K, Ahmed A. Audit of measles cases in a tertiary care hospital. Pak Paed J 20 I 3;37(3): I43-8.

19. Saleem AF, Zaidi A, Ahmed A, Warraich $\mathrm{H}$, Mir F. Measles in children younger than 9 months in Pakistan. Indian Pediatr 2009;46 (I I): 1009-I 2.
20. Tariq P. Assessment of coverage levels of single dose measles vaccine. J Coll Physicians Surg Pak 2003;13(9):50710.

2I. Furrukh M, Jalil A, Anwar S, Aslam Z, Javed T. Measles-Demographics and vaccination status. J Rawalpindi Med Coll Students Suppl 2015:19(S-I):2I 3.

22. Akramuzzaman SM, Cutts FT, Hossain MJ, Wahedi OK, Nahar N, Islam D, et al. Measles vaccine effectiveness and risk factors for measles in Dhaka, Bangladesh. Bull World Health Organ 2002; 80(I0):776-82.

23. Zahidie A, Wasim S, Fatmi Z. Vaccine effectiveness and risk factors associated with measles among children presenting to the hospitals of Karachi, Pakistan. J Coll Physicians Surg Pak 20 I 4;24 (I2):882-8.

24. Silfverdal SA, Ehlin A, Montgomery SM. Breast feeding and a subsequent diagnosis of measles. Acta Paediatr 2009;98(4):7I5-9. DOI:10.1III/j. |65|-2227.2008. 01 |80.x.

25. Indwar P, Debnath F, Sinha A. Reporting measles case fatality due to complications from a tertiary care hospital of Kolkata, West Bengal 20 I I 2013. J Family Med Prim Care 20I6;5(4):777-9. DOI: 10.4I03/2249.
4863.20II6I.

26. Ali S. Health for all in Pakistan: achievements, strategies and challenges. East Mediterr Health J 2000;6(4):832-7.

27. Orenstein WA, Cairns L, Hinman A Nkowane B, Olivé J-M, Reingold AL. Measles and Rubella Global Strategic Plan 2012-2020 midterm review report: Background and summary. Vaccine 2018;36:A35-A42. DOI: 10.1016/j.vaccine. 2017.10.065.

28. Rahim F, Rehman H, Afridi J. Measlesdemographic profile and complications in children. J Med Sci 20। I; I 9(4): I 74-6.

29. Onyiriuka AN. Clinical profile of children presenting with measles in a Nigerian secondary health-care institution. J Infect Dis Immun 20II;3(6): II2-6

30. Bugvi AS, Rahat R, Zakar R, Zakar MZ, Fischer F, Nasrullah $M$, et al. Factors associated with non-utilization of child immunization in Pakistan: evidence from the Demographic and Health Survey 2006-07. BMC Public Health 20I4; I4(I):232. DOI:I0.II86/ I47I2458-14-232

\section{AUTHORS' CONTRIBUTIONS}

Following authors have made substantial contributions to the manuscript as under:

FK \& AJG: Concept, study design, critical revision, final approval.

FK \& IA: Acquisition \& analysis of data, drafting the manuscript, critical revision, final approval.

RZ \& WA: Acquisition of data, critical revision, final approval.

Authors agree to be accountable for all aspects of the work in ensuring that questions related to the accuracy or integrity of any part of the work are appropriately investigated and resolved.

CONFLICT OF INTEREST
Authors declared no conflict of interest
GRANT SUPPORT AND FINANCIAL DISCLOSURE
NIL

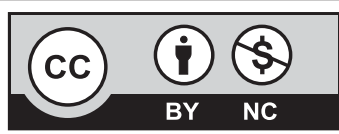

This is an Open Access article distributed under the terms of the Creative Commons Attribution-Non Commercial 2.0 Generic License.

KMUJ web address: www.kmuj.kmu.edu.pk

Email address: kmuj@kmu.edu.pk 